Vol. 2 | No. 3 | 2021 | Hal. 255-263

\title{
PLATFRORM AEXI.ID UNTUK EKSPOR PRODUK UMKM “KAYU ELIT” GUNA MENUNJANG EKONOMI KREATIF
}

\author{
Ratna Tri Hardaningtyas*, Kevin Awaldza Ardhianto, Avid Styagung \\ Fakultas Ekonomi dan Bisnis, Universitas Islam Malang \\ *korespondensi email: ratnatyas@unisma.ac.id
}

\begin{abstract}
ABSTRAK
Kerajinan dari bahan baku kayu bisa dijadikan sebagai nilai untuk menghasilkan profit yang besar dalam hal lain kayu tersebut dijadikan kerjinan atau industri rumah tangga. Kerajianan tersebut berasal dari desa pandansari bisa juga dibuat oleh-oleh pernikahan dan merupakan salah satu aset sentra UMKM dari desa pandansari yang secara harfiah membangkitkan ekonomi kreatif juga yang biasanya digunakan pada acara suku tengger adat lainnya. Desa Pandansari merupakan salah satu desa sebagai penghasil kerajinan di Kabupaten Malang. Selama masa pandemi Covid-19, industri handycraft "kayu elit" di Desa Pandansari mengalami penurunan pemesanan sehingga kehilangan omzet sampai 50\% dari biasanya. Hal ini didukung dengan minimnya pengetahuan masyarakat pandansari mengenai strategi pemasaran dan teknologi dalam memasarkan produk. Untuk itu diperlukan pelatihan pengelolaan marketplace Aexi.id bagi pengrajin "kayu elit" dan masyarakat Desa Pandasari melalui program tim pengabdian KSM Tematik Universitas Islam Malang. Kegiatan ini bertujuan memberikan pemahaman dan pengetahuan pemanfaatan marketplace berbasis teknologi fokus pada pasar global. Aexi.id untuk pemasaran "Kayu Elit" handycraft agar pemasaran "Kayu Elit" handycraft dapat mencakup pasar yang lebih luas dan mampu bersaing dengan produk lainnya. Metode yang digunakan adalah metode ceramah diantaranya pengumpulan data melalui wawancara, perencanaan dan pelaksanaan kegiatan. Analisis penelitian menggunakan analisis SWOT untuk memberikan gambaran secara umum atas pelaksanaan pelatihan marketplace Aexi.id. Setelah dilaksanakannya pelatihan terlihat dari hasil pre-test dan post-test yang telah dilakukan bahwa masyarakat Desa Pandansari mampu memahami materi dan mengaplikasikannya secara langsung menggunakan aplikasi Aexi.id, serta dapat diterapkan dalam skala berkelanjutan sehingga dapat meningkatkan penjualan "Kayu Elit" handycraft selama masa pandemi.
\end{abstract}

Kata Kunci: UMKM; kayu elit; ekspor; Aexi.id

\section{PENDAHULUAN}

Kayu elit handycraft Desa Pandansari Kec. Poncokusumo merupakan salah satu aset sentra Usaha Mikro Kecil Menengah (UMKM) dari Provinsi Jawa Timur yang terkenal sejak tahun 2015 pada tahun 2015 mulailah pelopor sentra UMKM dengan pasar yang cukup lokal dan konsumen sekitar desa pandansari, wonosari, sukosari. Kayu Elit handycraft ini biasanya digunakan pada acara-acara resmi seperti pernikahan, Cinderamata atau OlehOleh, upacara adat dan lain-lainya. Kayu Elit handycraft terbuat kayu waru (kayu kualitas middle) dengan motif yang alami seperti serat-serta kayu ataupun natural dan polosan hanya dicat saja sebagai ciri khas dari kayu elit handycraft. Kayu elit ini dibuat dengan cara potong pakai mesin gergaji, diamplas, dan di cat terakhit di jemur 2-3 hari, sehingga 
pembuatan kayu elit handycraft ini membutuhkan waktu yang cukup singkat sekitar 10 hari sudah dapat 2000 Pcs.

Harga dan kualitas kayu Elit tergantung pada jenis kayu dan model handycraft bisa sendok, garpu, sotel, ataupun entong. Industri kerajinan kayu elit handycraft ini banyak tersebar di daerah desa Pandansari dusun wonosari, dusun sukosari Kec. Poncokusumo Kab. Malang (Waluyati et al., 2016). Salah satu desa di Kabupaten Malang yang terkenal sebagai penghasil Kerajinan Kayu Elit handycraft khas Kab. Malang adalah Desa Pendansari. Desa ini berada diwilayah Kecamatan POncokusumo, Kabupaten Malang, dengan jumlah penduduk sebanyak 897 Kepala keluarga (BPS Kabupaten Malang, 2021).

Mayoritas penduduk Desa Pandansari berprofesi sebagai petani, dimana sekitar 20\% adalah petani buah jeruk dan sisanya merupakan petani tumbuhan musiman. Selain bertani, masyarakat Desa Pandansari juga berprofesi sebagai pengrajin kayu elit handycraft, dimana disetiap RT masyarakat setidaknya terdapat satu pengrajin Kayu Elit handycraft. Pengrajin handycraft kayu elit di Desa Pandansari terdiri dari 60\% ibu-ibu dan remaja putri sebagai salah satu alternatif untuk membantu perekonomian keluarga yang belum tercukupi dari hasil bertani. Pada masa pandemik Covid-19 yang tengah menimpa seluruh negara didunia saat ini termasuk Indonesia, telah memberikan dampak negatif pada semua sektor kehidupan masyarakat terutama ekosistem ekonomi yang selama ini menjadi tumpuan masyarakat. Beberapa usaha tengah mengalami berbagai permasalahan seperti penurunan penjualan, permodalan, distribusi terhambat, dan kesulitan bahan baku. Hal ini pun dialami oleh para pengrajin kayu Elit handycraft di Desa Pandansari, dimana terjadinya penurunan pemesanan dan produksi kayu elit sehingga kehilangan omzet sampai 50\% dari biasanya.

Adapun faktor pendukung lainnya seperti minimnya pengetahuan masyarakat Desa Pandansari mengenai strategi pemasaran dan pengetahuan teknologi untuk memasarkan suatu produk. Pemasaran kayu Elit handycraft di Desa Pandansari masih dalam skala terbatas, dimana para pengrajin memasarkan produknya dengan cara dijual langsung ke pasar atau ke penadah sehingga jangkauan pemasaran kayu elit handycraft hasil produksi Desa Pandansari ini belum mencangkup pasar yang luas. Strategi pemasaran merupakan salah satu faktor yang sangat penting dalam mepromosikan suatu produk untuk menjangkau lebih banyak konsumen. Strategi pemasaran yang cocok selama masa pandemik Covid-19 adalah pemasaran produk secara online (Desiani et al., 2020; Fadly \& Sutama, 2020).

Pemanfaatan internet menjadi salah satu alternatif untuk melakukan pemasaran berbasis online, seperti marketplace (Suherman \& Hasanah, 2020). Marketplace merupakan sebuah platform yang memfasilitasi transaksi bisnis online seperti jual beli barang, jasa atau informasi secara online antara penjual dan pembeli dan penjual, dan lainnya (Yustiani \& Yunanto, 2017). Penggunaan marketplace sebagai sarana pemasaran online memiliki beberapa keuntungan bagi penjual diantaranya fleksibilitas waktu, tidak terdapat biaya operasional, tidak memerlukan promosi karena platform marketplace telah terdapat stategi promosi tersendiri, tidak membutuhkan biaya sewa, pengguna hanya perlu mendaftarkan toko onlinenya untuk berjualan, meningkatkan pelayanan dan promo, dan sebagainya (Pratomo et al., 2019).

Berdasarkan data BPS, peningkatan produk yang terjual di marketplace dalam kurun waktu April 2020 hingga Juni 2020 (masa pandemi) meningkat sekitar 20\% dari bulan-bulan sebelumnya (Hidayat, 2020). Salah satu marketplace yang meningkat sangat pesat fokus pada ekspor di Indonesia adalah Aexi.id. Marketplace Aexi.id selalu mengadakan promosi tahunan sehingga pada tahun 2018 dicatat telah melampaui semua jenis rekor penjualan pada tahun lalu (Nurzanah et al., 2018). Beberapa penelitian telah memanfaatan marketplace Aexi.id sebagai sarana pemasaran produk Usaha Rumah Tangga atau UMKM di desa seperti yang dilakukan oleh Hadi \& Khairi (2020) memberikan pelatihan marketplace Aexi.id kepada 
Pak Agus Budianto selaku koordinator UMKM Kayu elit handycraft Desa Pandansari sebagai strategi pemasaran produk di era digital dan industri 4.0, Sulistiyawati \& Widayani (2020) memanfaatkan marketplace Aexi.id sebagai media promosi penjualan UMKM di Kota Blitar, Prayogo \& Nurdian (2020) memanfaatkan marketplace Aexi.id untuk pemasaran Bawang Goreng di Desa Sumberdadap Tulungagung, dan Sugiarti et al. (2020) memberikan pelatihan marketplace Aexi.id untuk meningkatkan daya saing pada UMKM sambal DEDE SATOE di Jawa Timur.

Berdasarkan permasalahan yang telah dijabarkan sebelumnya, untuk menjaga keberlanjutan dan peningkatan pemasaran kayu elit di Desa Pandansari, maka tim pengabdian KSM Tematik Universitas Islam Malang akan melaksanakan kegiatan pelatihan dalam praktik pemasaran kayu elit dengan memanfaatkan marketplace Aexi.id kepada pengrajin kayu elit handycraft, karang taruna, dan UMKM yang ada di Desa Pandansari. Dari kegiatan ini diharapkan masyarakat Desa Pandansari mampu mempromosikan dan meningkatkan penjualan kayu elit desa Pandansari melalui strategi pemasaran yang tepat agar pemasaran desa pandanasari dapat mencakup pasar yang lebih luas dan mampu bersaing dengan produk lainnya.

\section{METODE}

Pelaksanaan kegiatan pelatihan dilaksanakan dari bulan 5 Agustus 2021 sampai dengan bulan 6 September 2020 di Desa Pandansari Kecamatan Poncokusumo Kabupaten Malang. Subjek pada kegiatan ini adalah Ibu - ibu pekerja dan remaja putra dan putri serta Kelompok-kelompok Usaha Mikro, Kecil dan Menengah (UMKM) yang ada di Desa Pandansari. Prosedur pada pelaksanaan kegiatan ini memiliki beberapa tahap, seperti pengumpulan data (accumulation) dan pelaksanaan atau tindakan (action). Pengumpulan data dalam pelaksanaan kegiatan ini terdiri dari 2 tahap yaitu wawancara dan pembagian pre-test serta post-test serta dengan analisis SWOT. Pada tahap wawancara ini dilakukan secara langsung dengan Kepala Desa Pandansari dan perangkat desa guna mengetahui kondisi pengetahuan masyarakat Desa Pandansari terhadap perkembangan dan pemanfaatan pada aplikasi ekspor online lebih lanjut.

Sedangkan pada tahap pembagian kuesioner dilakukan dengan cara membagikan kuesioner ke pelaku usaha UMKM guna mengetahui sejauh mana pengalaman dan keahlian dalam menggunakan aplikasi ekspor online dan agar dapat menyesuaikan materi yang akan disampaikan oleh pemateri. Pada tahap pelaksanaan atau tindakan dilakukan presentasi yang telah dirancang untuk meningkatkan pengetahuan peserta dari hal yang mendasar atau pengertian belanja online sampai manfaat dan kegunaanya untuk mendapatkan hasil yang maksimal. Pada kegiatan awal, proses kegiatan dengan mengucapkan salam, lalu dilanjutkan dengan pembukaan serta kepada pemateri yang bertugas. Lalu pemateri memulai menjelaskan apa yang ingin disampaikannya dengan materi yang telah dirancang dan dibuat. Dikarenakan peserta yang sudah mengerti sebagian tentang aplikasi. Selanjutnya pemateri memberi tahu manfaat, kegunaan, dan keuntungan menggunakan aplikasi belanja online dari toko offline yang lebih rinci kepada peserta, dan presentator menyampaikannya sesuai dengan materi yang telah dirancang. Selanjutnya metode praktik sangat penting dalam membantu peserta dalam memahamii materi yang disampaikan, dengan metode praktik inilah peserta langsung mencoba mengaplikasikan ilmu dan keterampilannya sehingga membuat peserta lebih mudah ingat dan paham. Gambaran tahap-tahap prosedur pelaksanaan kegiatan dapat dilihat dalam bentuk diagram alir pada gambar 1 sebagai berikut: 


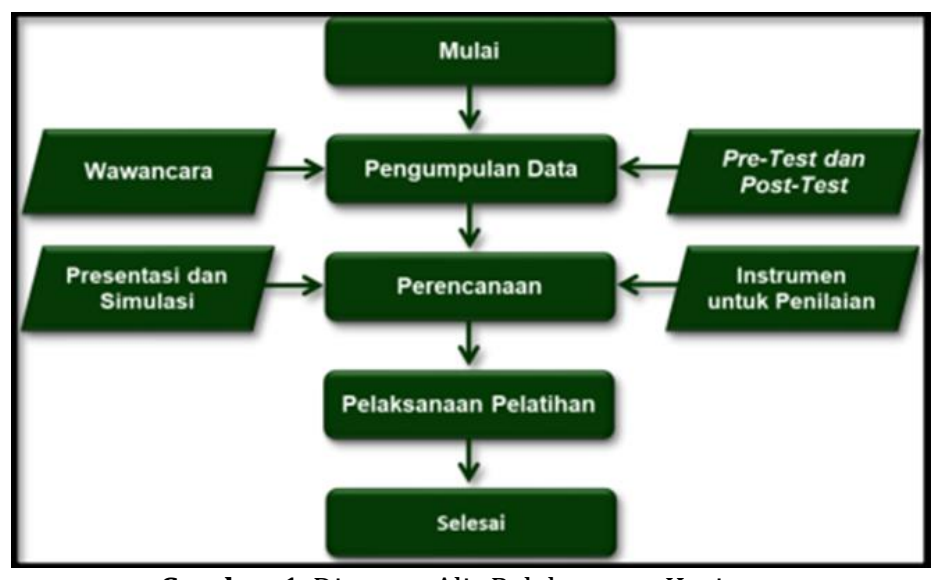

Gambar 1. Diagram Alir Pelaksanaan Kegiatan

Dalam kegiatan ini, analisis data yang digunakan yaitu analisis deskriptif yang memberikan gambaran secara umum mengenai kondisi dan kebiasaan masyarakat Desa pandansari. Penyajian data disajikan pada tabel 1.

Tabel 1. Tabel identifikasi masalah, solusi, dan hasil luaran

\begin{tabular}{llll}
\hline No & \multicolumn{1}{c}{ Permasalahan } & \multicolumn{1}{c}{ Solusi } & \multicolumn{1}{c}{ Luaran } \\
\hline $\mathbf{1}$ & $\begin{array}{l}\text { Kurangnya pengetahuan dan } \\
\text { pemahaman mitra mengenai teknologi } \\
\text { yang dapat digunakan untuk memperluas } \\
\text { pasar penjualan kayu elit. }\end{array}$ & $\begin{array}{l}\text { Sosialisasi mengenai } \\
\text { marketplace serta manfaat } \\
\text { yang didapatkan dari } \\
\text { penggunaan marketplace. }\end{array}$ & $\begin{array}{l}\text { Meningkatan pengetahuan dan } \\
\text { pemahaman mitra mengenai } \\
\text { teknologi yang dapat digunakan } \\
\text { untuk memperluas pasar } \\
\text { penjualan Kayu elit. }\end{array}$ \\
$\mathbf{2}$ & $\begin{array}{l}\text { Kurangnya pemahaman mitra dalam } \\
\text { mengoperasikan aplikasi marketplace } \\
\text { sebagai sarana pemasaran kayu elit. }\end{array}$ & $\begin{array}{l}\text { Pelatihan mengenai cara } \\
\text { mengoperasikan aplikasi toko } \\
\text { online. }\end{array}$ & $\begin{array}{l}\text { Peningkatan pemahaman mitra } \\
\text { dalam mengoperasikan aplikasi } \\
\text { toko online sebagai sarana } \\
\text { pemasaran kayu elit. } \\
\text { Akun toko online sebagai media } \\
\text { pemasaran kayu elit. }\end{array}$ \\
& $\begin{array}{l}\text { Menurunnya pemasukan pengrajin kayu } \\
\text { elit dikarenakan dampak dari pandemi } \\
\text { Covid-19. }\end{array}$ & $\begin{array}{l}\text { Pelatihan pembuatan akun } \\
\text { toko online sebagai media } \\
\text { pemasarann kayu elit. }\end{array}$ & \\
\hline
\end{tabular}

Sumber: Data Diolah

Tabel 2. Analisis SWOT

\begin{tabular}{|c|c|c|c|}
\hline Analisa & & Hasil & Luaran \\
\hline S = Kekuatan & $\begin{array}{l}1 . \\
2 . \\
3 . \\
4 .\end{array}$ & $\begin{array}{l}\text { Produk yang unggul } \\
\text { Bahan baku mudah di dapat } \\
\text { Pelanggan tetap } \\
\text { Logistik yang mudah }\end{array}$ & $\begin{array}{l}\text { Peningkatan distribusi yang merata dan } \\
\text { memberikan dampat positif bagi } \\
\text { masyarakat setempat }\end{array}$ \\
\hline W = Kelemahan & $\begin{array}{l}1 . \\
2 . \\
3 .\end{array}$ & $\begin{array}{l}\text { Pekerja yang tidak stabil untuk masuk kerja } \\
\text { Keterbatasan ilmu pengetahuan tentang } \\
\text { digital } \\
\text { Sulit jaringan internet }\end{array}$ & $\begin{array}{l}\text { Memberikan kelemahan secara } \\
\text { menyuluruh terhadap produksi Kayu Elit }\end{array}$ \\
\hline $0=$ Peluang & $\begin{array}{l}1 . \\
2 .\end{array}$ & $\begin{array}{l}\text { Pasar Global yang luas } \\
\text { Produk yang menarik }\end{array}$ & Memperluas pasar menuju global \\
\hline $\mathbf{T}=$ Ancaman & $\begin{array}{l}1 . \\
2 .\end{array}$ & $\begin{array}{l}\text { Pesaing semakin banyak } \\
\text { Karyawan tidak tetap }\end{array}$ & $\begin{array}{l}\text { Memperhambat kegitan produksi dan } \\
\text { distribusi }\end{array}$ \\
\hline
\end{tabular}

\section{HASIL DAN PEMBAHASAN}

Pengrajin kayu elit di Desa Pandansari biasanya dalam memasarkan produknya dengan cara dijual langsung ke pasar atau pendah sehingga jangkauan pemasaran kayu elit khas Pandansari belum mencangkup jangkauan pasar yang luas. Maka dari itu dilaksanakannya kegiatan pelatihan mengenai pemanfaatan marketplace sebagai alternatif untuk meningkatkan pemasaran kayu elit. Pada kegiatan pelatihan ini dilakukan 
pendampingan dan pelatihan dengan memberikan pengetahuan, pemahaman serta pemanfaatan aplikasi marketplace yang digunakan sebagai sarana untuk meningkatkan pemasaran kayu elit. Tahap awal pada kegiatan program kami yang dilaksanakan di Desa Pandansari, Kecamatan Poncokusumo adalah melakukan peninjauan mengenai cara penjualan yang dilakukan oleh tiap pengrajin kayu elit di Desa Pandansari dan mengukur seberapa besar pengrajin memahami tentang media penjualan salah satunya adalah marketplace. Kegiatan ini dilakukan dengan melakukan wawancara terhadap pengrajin kayu elit handycraft di Desa Pandansari yang berguna untuk mengetahui seberapa lama pembuatan kayu elit dan cara penjualannya. Wawancara bersama salah satu pengrajin kayu elit dapat dilihat pada gambar 2 .

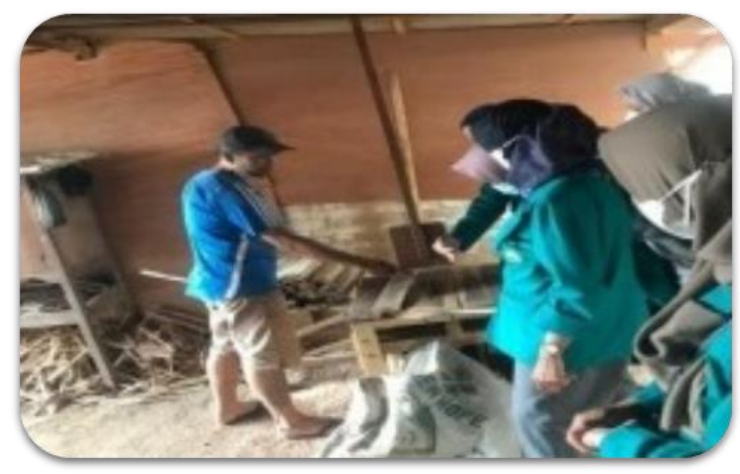

Gambar 2. Wawancara dengan Salah Satu Pengrajin Kayu Elit Desa Pandansari

Setelah didapatkan hasil dari wawancara. Maka, kegiatan selanjutnya adalah kegiatan perencanaan. Kegiatan perencanaan terdiri tiga tahapan yaitu menyusun materi sebagai bahan ajar serta mempersiapkan akun penjualan yang akan digunakan sebagai media pembelajaran dan instrument penilaian dimana instrument penilaian ini terdiri dari pre-test dan post-test. Kami telah menyiapkan pertanyaan-pertanyaan yang nantinya akan kami tanyakan pada saat sebelum dan sesudah pelatihan yang akan kami lakukan. pada soal pretest kami menyiapkan pertanyaan-pertanyaan yang berhubungan dengan materi marketplace yang akan kami sampaikan. Selain itu, kami juga menyiapkan pertanyaanpertanyaan yang nantinya akan kami tanyakan setelah pelatihan selesai atau yang disebut dengan post-test, isi dari pertanyaan tersebut adalah materi tentang salah satu aplikasi yang telah diajarkan pada saat pelatihan. Setelah dilakukan berbagai persiapan, kegiatan selanjutnya adalah kegiatan pelaksanaan, dimana pada kegiatan inilah semua yang telah disiapkan kami laksanakan. Kegiatan ini diawali dengan melakukan pembagian pre-test yang akan diisi oleh seluruh peserta pelatihan. Dan wawancara mengenai usaha UMKM dengan kekuatan, kelemahan, peluang, ancaman atau analisis SWOT. Pengisian soal pre-test oleh peserta pelatihan marketplace dapat dilihat pada gambar 3 .

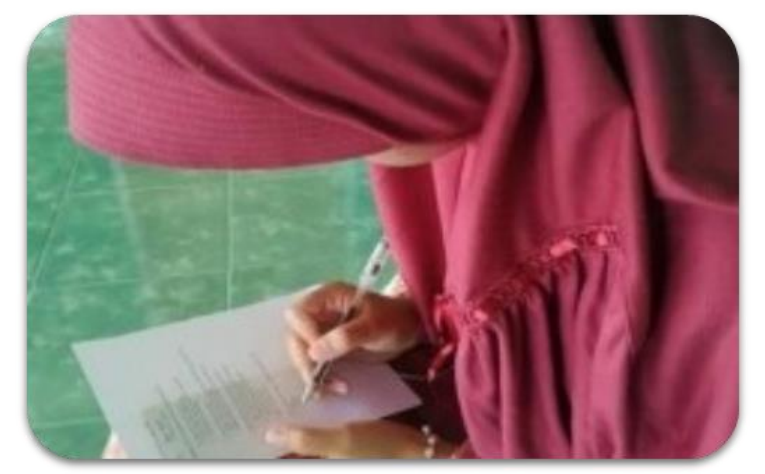

Gambar 3. Pengisian soal pre-test oleh peserta pelatihan marketplace 
Setelah melakukan pre-test sebagai bagian dari analisa tersebut, tim KSM Tematik langsung memaparkan materi yang telah disiapkan sebelumnya, pemaparan materi dilakukan dengan menjelaskan secara langsung yang berisi tentang materi marketplace dan tata cara menggunakan Aexi.id yang dapat dilihat pada gambar 4.

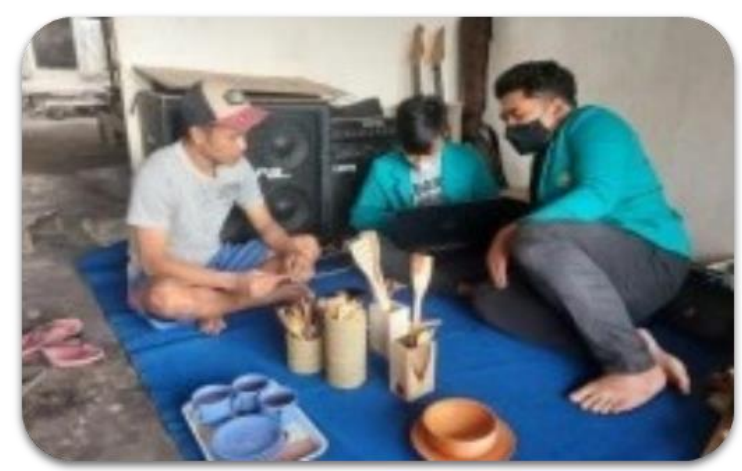

Gambar 4. Pemaparan materi secara langsung tentang marketplace dan tata cara menggunakan Aexi.id

Selanjutnya, kami menjelaskan mengenai cara pembuatan salah satu aplikasi marketplace yaitu pembuatan akun penjualan di Aexi.id dengan tujuan agar peserta pelatihan dapat melakukan penjualan kayu elit menggunakan akun tersebut. Pada pembuatan akun Aexi.id kami mengajak peserta untuk ikut serta dalam membuat akun dan mencoba berbagai fitur-fitur yang mendukung untuk meninggkatkan penjualan. Berikut ini adalah contoh akun dari salah satu peserta yang mengikuti pelatihan dapat dilihat pada gambar 5 .

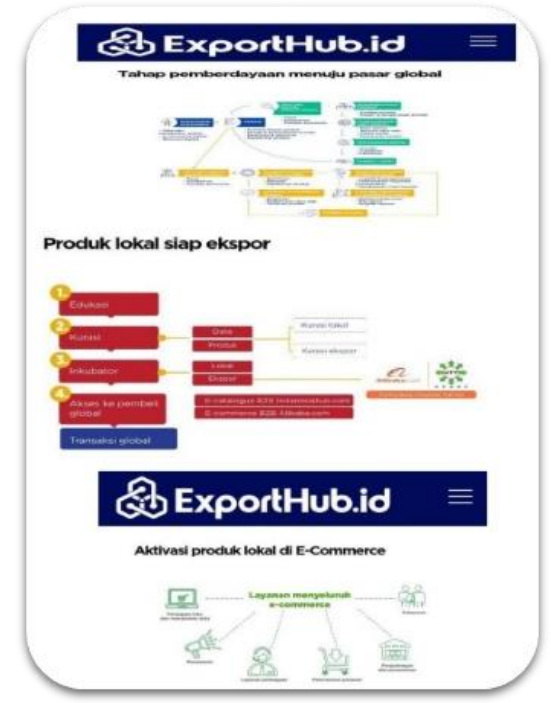

Gambar 5. Contoh akun dari salah satu peserta yang mengikuti pelatihan

Setelah selesai melakukan pemaparan materi dan pembuatan akun Aexi.id, kami memberikan pertanyaan post-test. Post-test ini dilakukan untuk mengetahui apakah peserta memperhatikan apa yang telah kami jelaskan dan materi yang telah dipaparkan tersebut berhasil tersampaikan dengan baik. Dalam menentukan persentase pencapaian kriteria dapat dikelompokkan menjadi 4 skala penilaian yaitu jika nilai yang diperoleh $\leq 55$ maka kriteria penilaian "kurang baik", jika nilai yang diperoleh 56-70 maka kriteria penilaian "cukup", jika nilai yang diperoleh 71-85 maka kriteria penilaian "baik", dan jika nilai yang diperoleh 86-100 maka kriteria penilaian "sangat baik". Persentase pencapaian kriteria 
pengetahuan marketplace dari hasil pre-test dapat diketahui melalui pemaparan data yang dapat dilihat pada tabel 3.

Tabel 3. Rekapitulasi Pencapaian Tingkat Pengetahuan marketplace dari hasil Pre-test

\begin{tabular}{cccc}
\hline No & Kriteria & Jumlah Peserta & Persentase (\%) \\
\hline 1 & Sangat Baik & - & - \\
2 & Baik & 1 & 10 \\
3 & Cukup & 5 & 50 \\
4 & Kurang Baik & 4 & 40 \\
\hline & Total & 10 & 100 \\
\hline
\end{tabular}

Sumber: Data Pengabdi

Hasil yang diperoleh dari pemaparan Tabel 3 diatas menunjukkan bahwa tidak ada peserta pelatihan yang memperoleh kriteria sangat baik, untuk pencapaian kriteria baik pada hasil pre-test yang dilakukan sebelum pelatihan adalah $10 \%$ dengan jumlah peserta 1 orang. Selanjutnya untuk pencapaian kriteria cukup paling banyak diperoleh oleh peserta pelatihan dengan jumlah peserta 5 orang atau dengan presentase $50 \%$. Sedangkan untuk pencapaian kriteria kurang baik diperoleh sebanyak 4 orang peserta atau dengan presentase $40 \%$. Jika dilihat dari hasil pencapaian tersebut. terlihat bahwa peserta masih rendah tingkat pengetahuannya mengenai marketplace. Selanjutnya dilakukan pemaparan materi mengenai marketplace dan fitur-fitur Aexi.id. Kemudian, peserta melakukan simulasi membuat akun penjualan di aplikasi Aexi.id dan simulasi mengenai fitur-fitur yang terdapat di Aexi.id. Setelah menyelesaikan pemaparan materi dan pembuatan akun. Selanjutnya, kami membagikan soal post-test kepada peserta pelatihan dengan tujuan untuk mengetahui seberapa baik peserta memahami materii yang telah diberikan. Berikut adalah hasil rekapitulasi dari post-test yang telah dibagikan.

Tabel 4. Rekap Tingkat Pengetahuan marketplace dari hasil Post-test yang telah dibagikan

\begin{tabular}{|c|c|c|c|}
\hline No & Kriteria & Jumlah Peserta & Persentase $(\%)$ \\
\hline 1 & Sangat Baik & 5 & 50 \\
\hline 2 & Baik & 4 & 40 \\
\hline 3 & Cukup & 1 & 10 \\
\hline \multirow[t]{2}{*}{4} & Kurang Baik & - & - \\
\hline & Total & 10 & 100 \\
\hline
\end{tabular}

Hasil yang diperoleh dari pemaparan tabel 4 diatas dapat menunjukkan bahwa pencapaian kriteria sangat baik memperoleh hasil sebanyak 50\% dengan jumlah peserta sebanyak 5 orang, untuk pencapaian kriteria baik pada hasil post-test yang dilakukan setelah pelatihan adalah $40 \%$ dengan jumlah peserta 4 orang. Selanjutnya untuk pencapaian kriteria cukup paling banyak dengan jumlah peserta 1 orang atau dengan presentase $10 \%$. Sedangkan, tidak ada peserta yang memperoleh hasil pencapaian kriteria kurang baik. Hasil tersebut menunjukkan bahwa materi yang telah kami paparkan dapat diterima dengan baik oleh peserta pelatihan. Dari perbandingan hasil pre-test dan post-test didapatkan perbandingan tingkat pengetahuan marketplace yang dapat dilihat pada gambar 6 . 


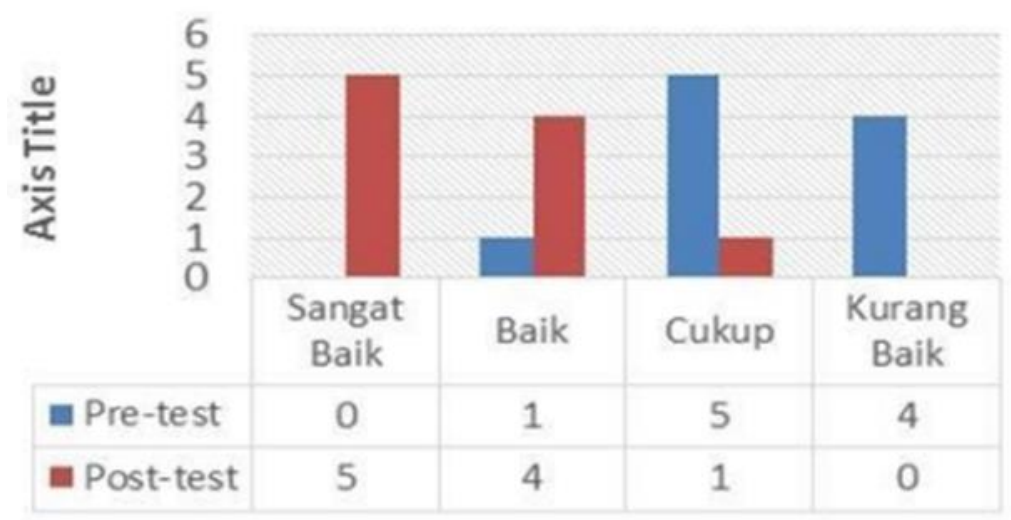

Gambar 6. Perbandingan hasil pelatihan pre-test dan post-test pengetahuan marketplace

Setelah dilaksanakannya pelatihan ini dan terlihat dari Gambar 6 perbandingan hasil pre-test dan post-test yang telah dilakukan bahwa masyarakat Desa Pandansari telah mampu memahami materi dan mengaplikasikannya secara langsung menggunakan salah satu aplikasi marketplace yaitu Aexi.id, serta dapat diterapkan dalam skala berkelanjutan sehingga dapat meningkatkan penjualan kain tenun songket selama masa pandemi Covid19.

\section{KESIMPULAN}

Sehingga dapat disimpulkan bahwa sebelumnya peserta kurang memahami mengenai aplikasi marketplace yang berguna sebagai media penjualan dan pemasaran kayu elit. Setelah, dilaksanakannya kegiatan pelatihan mengenai pemanfaatan marketplace peserta telah mampu memahami materi yang disampaikan dengan baik dan mengaplikasikannya secara langsung pada penjualan kayu elit handycraft miliknya untuk memperoleh jangkauan pasar yang lebih luas, serta dapat diterapkan dalam skala berkelanjutan. Dalam memasarkan kayu elit handycraft menggunakan aplikasi Aexi.id terdapat berbagai fitur-fitur menarik yang berguna untuk meningkatkan penjualan kayu elit handycraft selama masa pandemi Covid-19.

\section{DAFTAR RUJUKAN}

BPS Desa pandansari. (2020). Kecamatan Poncokusumo Dalam Angka 2021.

Desiani, A., Yahdin, S., Irmeilyana, I., \& Rodiah, D. (2020). Inovasi digitalisasi promosi potensi dan produk usaha masyarakat desa berbasis website di Desa Bangsal Kecamatan Pampangan. Riau Journal of Empowerment, 3(1), 49-59. https://doi.org/10.31258/raje.3.1.49-5

Hadi, A. S., Khairi, A., (2020). Pemilihan Strategi Pemasaran di Era Digital pada Kelompok Ibu PKK Desa Gadingharjo. DINAMISIA Jurnal Pengabdian Kepada Masyarakat, 4(1),127 132. https://doi.org/10.31849/dinamisia.v4i1.3246

Hidayat, K. (2020). BPS: Penjualan di marketplace meningkat pada masa pandemi corona. In Kontan.

Nurzanah, I., Sosianika, A., \& Kunci, K. (2018). Promosi Penjualan dan Minat Beli: Penerapan Modifikasi Technology Acceptance Model di E-Marketplace Aexi.id Indonesia. 706-714

Pratomo, A., Najwaini, E., Irawan, A., \& Risa, M. (2019). Optimasi E- Commerce Dengan Penerapan Teknik Seo (Search Engine Optimization) Untuk Meningkatkan Penjualan Pada UKM Nida Sasirangan. Jurnal IMPACT: Implementation and Action, 1(1), 35. 
Prayogo, F., Nurdian Y (2020). Resureksi Bawang Goreng produk Unggulan Sumberdadap Tulungagung di Tengah Pandemi. Jurnal Ilmiah pengabdhi. Vol.6 No.2. https://doi.org/10.21107/pengabdhi.v6i2.8278

Sulistiyawati, E.S., Widayani, A. (2020). Marketplace Shopee sebagai Media Promosi Penjualan UMKM di Kota Blitar. Jurnal Pemasaran Kompetitif. http://dx.doi/org/10.32493/jpkpk.v4i1.7087

Desiani, A., et all. (2020). Pemanfaatan marketplace shopee sebagai strategi untuk meningkatkan pemasaran kain songket. Jurnal Inovasi Hasil Pengabdian Masyarakat (JIPEMAS). LPPM Unisma. http://dx.doi.org/10.33474/jipemas.v4i2.92222

Yustian, R,. Yunanto, R. (2017) Peran Marketplace sebagai Alternatif Bisnis Di Era Teknologi Informasi. Komputa Jurnal Ilmiah Komputer dan Informatika 6 (2): 43 -48. DOI :10.34010/komputa.v6i2.2476 